\title{
Perspective \\ Research Supporting a Pilot Study of Metronomic Dapsone
during Glioblastoma Chemoirradiation
}

Richard E. Kast

check for updates

Citation: Kast, R.E. Research Supporting a Pilot Study of Metronomic Dapsone during Glioblastoma Chemoirradiation. Med. Sci. 2021, 9, 12. https://doi.org/ 10.3390/medsci9010012

Received: 18 January 2021

Accepted: 10 February 2021

Published: 16 February 2021

Publisher's Note: MDPI stays neutral with regard to jurisdictional claims in published maps and institutional affiliations.
IIAIGC Study Center, Burlington, VT 05408, USA; richarderickast@gmail.com

\begin{abstract}
This short note presents previous research data supporting a pilot study of metronomic dapsone during the entire course of glioblastoma treatment. The reviewed data indicate that neutrophils are an integral part of human glioblastoma pathophysiology, contributing to or facilitating glioblastoma growth and treatment resistance. Neutrophils collect within glioblastoma by chemotaxis along several chemokine/cytokine gradients, prominently among which is interleukin-8. Old data from dermatology research has shown that the old and inexpensive generic drug dapsone inhibits neutrophils' chemotaxis along interleukin-8 gradients. It is on that basis that dapsone is used to treat neutrophilic dermatoses, for example, dermatitis herpetiformis, bullous pemphigoid, erlotinibrelated rash, and others. The hypothesis of this paper is that dapsone will reduce glioblastomas' neutrophil accumulations by the same mechanisms by which it reduces dermal neutrophil accumulations in the neutrophilic dermatoses. Dapsone would thereby reduce neutrophils' contributions to glioblastoma growth. Dapsone is not an ideal drug, however. It generates methemoglobinemia that occasionally is symptomatic. This generation is reduced by concomitant use of the antacid drug cimetidine. Given the uniform lethality of glioblastoma as of 2020, the risks of dapsone $100 \mathrm{mg}$ twice daily and cimetidine $400 \mathrm{mg}$ twice daily is low enough to warrant a judicious pilot study.
\end{abstract}

Keywords: dapsone; edema; glioblastoma; interleukin-8; myeloid derived suppressor cells; neutrophils

\section{Introduction}

\subsection{Background}

As things stand as of 2020, glioblastoma (GB) is uniformly fatal within a few years of initial diagnosis. This brief note reviews accumulated research data that, taken together, indicate that adding an old antibiotic, dapsone, to current standard treatment of GB may to some degree increase survival time. The expected benefit of adding dapsone might be small but welcome. The physiologic effects and pharmacological attributes of dapsone mesh with selected aspects of GB pathophysiology in a way predicted to retard GB growth.

\subsection{Dapsone}

Dapsone is a sulfone antibiotic continuously in use worldwide since the $1950 \mathrm{~s}$. The two main uses of dapsone as of the end of 2020 are 1) as antibiotic and 2) to treat the neutrophilic dermatoses [1]. Table 1 lists the basic pharmacologic parameters of dapsone. The database as of 2014, supporting adjunctive dapsone use during treatment of GB was presented in our previous series of papers on this [2-6]. The in vitro levels of dapsone needed to demonstrate glioma cell line direct cytotoxicity are supraphysiologic and probably not relevant [2]. Further data on dapsone, relevant to GB and accruing since 2014, is reviewed here. 
Table 1. Basic pharmacological parameters of dapsone. For references see text and Zuidema et al.

\begin{tabular}{|c|c|}
\hline Mol. wt. & 248 \\
\hline metabolism & N-glucuronidation, CYP 2C9, 2C19 \\
\hline metabolite & monoacetyl dapsone, half-life $22 \mathrm{~h}$ \\
\hline protein bound & $73 \%$ \\
\hline Half-life & $\sim 20-30 \mathrm{~h}$, blood \\
\hline single dose Cmax & $\sim 1 \mathrm{mcg} / \mathrm{mL},=\sim 1 \mathrm{mg} / \mathrm{L}=\sim 4$ microM \\
\hline Cmax, chronic & median $=16$ microM $=4 \mathrm{mcg} / \mathrm{mL}$ \\
\hline high blood level & $5 \%$ had $28 \mathrm{microM}=7 \mathrm{mcg} / \mathrm{mL}$ blood \\
\hline therapeutic range & 0.5 to $5 \mathrm{mcg} / \mathrm{mL}$ serum [as antibiotic] \\
\hline glioblastoma (GB) motility inhibition & $50 \mathrm{microM}=12 \mathrm{mcg} / \mathrm{mL}$, in vitro \\
\hline GB growth inhibition & $50 \mathrm{microM}=12 \mathrm{mcg} / \mathrm{mL}$, in vitro \\
\hline $50 \%$ IL-8 reduction & $25 \mathrm{microM}=6 \mathrm{mcg} / \mathrm{mL}$ \\
\hline Side effects $>5 \%$ & methemoglobinemia \\
\hline Side effects $1-5 \%$ & hemolytic anemia \\
\hline Side effects $<1 \%$ & agranulocytosis, hepatitis \\
\hline antibiotic use & $\begin{array}{l}\text { Hansen's disease, Pneumocystis, } \\
\text { Toxoplasmosis, Mycobacteria, malaria }\end{array}$ \\
\hline dermatology use & neutrophilic dermatoses, acne \\
\hline
\end{tabular}

As a sulfone antibiotic, dapsone is used in general medicine to treat various infectionsHansen's disease, Plasmodia, Pneumocystis, Toxoplasmodia, and others [7]. In dermatological practice, dapsone is used to treat a variety of neutrophilic dermatoses of non-microbial origin like bullous pemphigoid, dermatitis herpetiformis, urticarial dermatoses, cutaneous lupus, and others [7-10].

The collected data presented here indicates that dapsone has potential to diminish aspects of interleukin-8 (IL-8) (Section 2) and neutrophils' (Section 3) contributions to GB growth in part by similar mechanisms as it does in promoting healing in the neutrophilic dermatoses. Vide infra.

\section{Dapsone}

\section{1. $G B$ and $I L-8$}

IL-8 is integral to GB tumor cell proliferation, invasion, and vascular mimicry [11]. Details follow:

IL-8 is an $11 \mathrm{kDa}$ cytokine that comprises an integral, core feature of GB's pathophysiology [12]. In addition to the data collected and analyzed in our previous GB-related dapsone papers referenced above, recent reports confirm IL-8 as contributing to GB cells ${ }^{\prime}$ migration, vascular mimicry, and proliferation, as well as the established role of IL-8 as a central chemotaxic signal for neutrophil homing [11-15]. Autocrine IL-8 promotes motility in GB cells $[16,17]$ and drives (among many other factors) their growth $[18,19]$ as well as attracting neutrophils to areas of angiogenesis. Tissue from GB recurrences have increased expression of IL-8 compared to the initial tumor [18].

Irradiation prolongs survival in GB but also engages multiple growth-enhancing pathways, leading to more aggressive tumor on the heretofore inevitable regrowth $[20,21]$. As documented in other cancers, standard irradiation treatment increases IL-8 in GB: by microdialysis and stereotaxic biopsy analysis, greater irradiation-induced IL-8 increases are correlated with shorter overall survival [22]. Standard post-resection irradiation of GB also increased IL-8 in adjacent uninvolved brain tissue, thus forming a "fertilizing" tissue preparation for residual GB invasion and regrowth [22]. Such peritumoral IL-8 induced by irradiation is chemotactic to residual isolated intramural GB cells. This IL-8 increase in irradiation-exposed tissue - in both GB and normal tissues-are a major aspect driving irradiation-induced increased GB aggressiveness [21,23-25].

Greater GB expression of IL-8 receptor CXCR2 is also associated with shorter overall survival [26]. 


\subsection{Dapsone, IL-8, and Neutrophils}

Dapsone decreases IL-8 and interferes with IL-8 function in several settings [2,27-32]. Dapsone suppressed in vitro IL-8 production in human epidermal keratinocytes and in THP-1 leukaemic monocytes [33]. However, Bellon et al. showed no inhibition of IL-8 by dapsone in IL-1 alpha stimulated bronchial epithelial cells [34]. It is unknown if dapsone would lower IL-8 in the above-mentioned irradiation exposed brain tissue.

Necrotic islands surrounded by pseudopalisading dense sheets of hypoxic GB cells are a typical feature of GBs. Nearby these areas are dense collections of neutrophils. These hypoxic, necrotic areas stain heavily for IL-8 and are associated with shorter survival [35].

Elevated circulating IL-8 in GB, and the associated, consequent, neutrophil activation, as defined by CD11b expression, is associated with shorter GB survival [36]. Conclusion: IL-8 attraction of neutrophils to a growing GB is a pathophysiological parallel to the bullous and neutrophilic dermatoses.

\section{Dapsone, GB, and Neutrophils}

Neutrophils home along an IL-8 gradient and become activated in the presence of IL-8. Neutrophils contain fully $50 \%$ of total blood vascular endothelial growth factor (VEGF) [37-39]. Evidence from multiple experimental and clinical studies implicate neutrophils as a growth-enhancing link in GB pathophysiology. Some of that data accumulated since 2014 is reviewed below.

Denser neutrophil infiltration in human GB is associated with a shorter overall survival [40]. During standard temozolomide chemoirradiation, circulating neutrophil decreases of $\geq 40 \%$ predict a longer survival than those who do not have such a dip [41].

A defining feature of human GB is the presence of necrotic areas in proximity to dense neutrophil collections and pseudopalisades. Although necrosis as cause or effect of dense neutrophil pockets has not been established, a greater degree of such necrosis within a GB is associated with shorter survival [35,42]. Necrotic tumor areas characteristic of GB also stimulate nearby GB tissue to secrete increased IL-8 [35].

In a study of 2249 resected gliomas of all grades, increasing neutrophil content within the tumors correlated with increased malignancy grade and shorter overall survival [43].

Five independent studies in the last few years attested to both dexamethasone use and the neutrophilia and/or lymphocytopenia caused by dexamethasone use are correlated with shorter survival and clinically meaningful immunosuppression in GB [44-48].

In a study of prednisone use in giant cell arteritis, dapsone was found to be steroid sparing [49]. Were it so in GB, this alone would be of benefit in GB.

Promotion of malignant neovascularization and multiple other GB growth enhancing attributes of neutrophils exist, in addition to the above mentioned bearing of VEGF and IL8 [12,49-52]. VEGF, IL-8, interleukin-1 beta (IL-1b), and other neutrophil borne cytokines, not only participate in mediation of neovascularization in GB-these also increase resistance to temozolomide. It was therefore natural and expected when in early 2019 neutrophil tumor infiltration was shown to counteract bevacizumab (Avastin ${ }^{\mathrm{tm}}$ ) effectiveness in colon cancer [53] as it does in GB [54,55], further evidence that neutrophils indeed bring VEGF to a growing GB.

See Figure 1 showing neutrophils within or adherent to a venule wall of a human GB. Anti-VEGF immunohistochemistry stains red and red blood cells stain grey-green (thanks to A. Scheuerle, MD for this slide). 


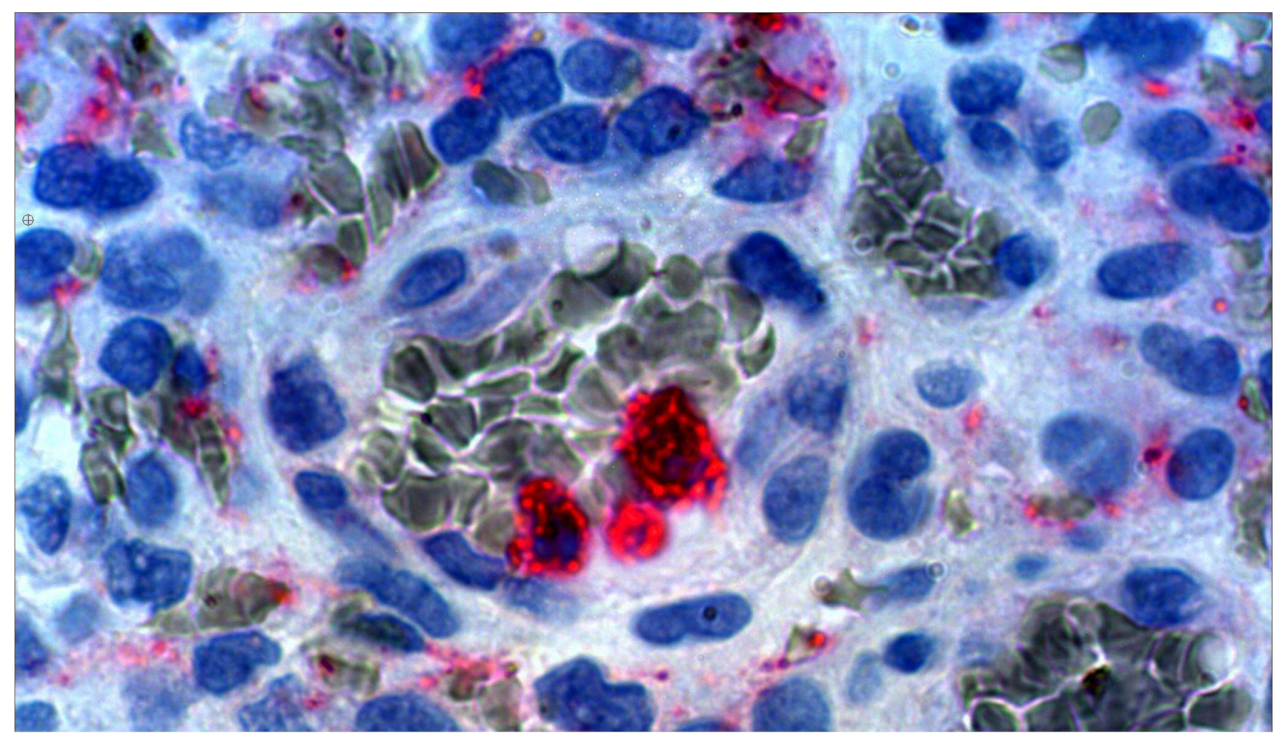

Figure 1. Micrograph, human GB $\times 100$ oil immersion with electronic magnification. Anti-VEGF stained (red) neutrophils and vascular endothelial growth factor (VEGF) containing debris. With permission, thanks to A. Scheuerle, MD for this slide.

In 2020, Owen-Woods et al. demonstrated that neutrophil binding, rolling, and migrating along, and penetration between, endothelial cells is a bidirectional feedback process that is both cause and an effect of tissue edema [56], thus forming an amplifying feedback system. It is by dapsone's potential to interrupt this amplifying feedback that dapsone may reduce the peritumoral edema characteristic of GB. Peritumoral edema is not just a mechanical problem - it is precisely the peritumoral edematous brain areas where GBs tend to recur [57].

A subset of neutrophils or neutrophil-like cells comprise the major component of myeloid derived suppressor cells present within GBs. They constitute an element of GB's immunosuppressive environment [58-63]. The preponderance of evidence in human cancers points to a growth enhancing role in naturally occurring malignant disease-hence dapsone. Intratumoral neutrophils are a negative prognostic sign in GB and interestingly positively correlated with programmed death ligand-1 expression [64,65].

Relevant to this statement, empirically, remarkably fully 13 independent studies just between 2018 and 2020 reported the same findings-that a higher neutrophil to lymphocyte ratio-a relative or absolute neutrophilia - correlated with shorter survival in GB [66-78]. Few parameters in any cancer have been so oft confirmed. This correlation also applied to pretreatment, pre-steroid GB use. While not a strong effect-for example overall survival 18 months with versus 24 months without relative neutrophilia would be typical-it is nevertheless strong evidence of a certain, if limited, growth promoting role of neutrophilsone worthy of inhibition if we can do so. Absolute neutrophil count, pre-operative, and pre-treatment neutrophil count greater than $7 \times 10^{9} / \mathrm{L}$ was a negative prognostic factor for OS [76].

By what specific intracellular mechanism of action dapsone reduces neutrophils' pro-inflammation behavior has not been established fully, but inhibition of neutrophils myeloperoxidase seems to be important [79]. Myeloperoxidase catalyzes the reaction: $\mathrm{H}_{2} \mathrm{O}_{2}+\mathrm{Cl}^{-}=\mathrm{H}_{2} \mathrm{O}+\mathrm{OCl}^{-}$. Dapsone, by binding to myeloperoxidase, lowers hypochlorite production. It should be noted here that GB patients have twice the level of myeloperoxidase both in plasma and in the GB tissue itself [80].

Of interest, neutrophil agglomerations form "hotspots" of concentrated serine hydrolases within GBs [81]. These are related to the neutrophil extracellular traps that are associated with GBs and worsen prognosis [78]. 


\section{Dapsone Safety}

Dapsone is not an ideal drug. Aplastic anemia, hypersensitivity reactions, and druginduced hepatitis are uncommon but real risks of dapsone use. Some degree of methemoglobinemia is universal with dapsone use but this is not usually symptomatic [82]. In a study of dapsone $100 \mathrm{mg} \times 1$ given over half a year to rheumatoid arthritis patients, $17 \%$ had to stop it due to side effects [83]. Considering the gravity of GB, many clinicians would consider the risk/benefit ratio to favor a pilot study of dapsone in GB.

Deps et al. found that as part of multidrug treatment (rifampin, clofazimine, dapsone) of 194 people with Hansen's disease, 25\% developed minor hemolytic anemia traceable to dapsone use (hematocrit fell 38 to 31) [82]. There have been isolated, single case reports of fatal fulminant hepatitis or agranulocytosis associated with dapsone use. Dapsone is considered safe enough for chronic use over many years in rheumatoid arthritis and lupus. Of note, dapsone reduces ESR and CRP in rheumatoid arthritis [82-85].

In their case series of dapsone use in treating various subtypes of cutaneous lupus erythematosus in 34 patients, Klebs et al. found that with an average dapsone dose of $100 \mathrm{mg}$ once daily, 11 of 17 people on dapsone as monotherapy experienced full remission of cutaneous signs and symptoms [86]. One developed elevated liver enzymes with eosinophilia and elevated CRP (drug reaction with eosinophilia and systemic symptoms (DRESS syndrome), one developed digit hyperesthesia after 7 months treatment, and one person developed hemolytic anemia (hemoglobin $9.7 \mathrm{~g} / \mathrm{dl}=6 \mathrm{mM}$ ) with $72 \%$ reticulocytes. All patients developed asymptomatic methemoglobinemia [86].

People with glucose-6-phosphate dehydrogenase (G-6-PD) deficiency may be at greater risk for hematological side effects. Low level methemoglobin can give subtle signs of reduced mental function, headache, or fatigue [87].

Caution must be taken when treating people with diabetes in that $\mathrm{HbA} 1 \mathrm{c}$ levels become unreliable during dapsone treatment [88]. Blood glucose measurement remains uninfluenced and valid.

It is important to note that in dermatitis herpetiformis, bullous pemphigoid, IgA dermatitis, and other neutrophilic dermatoses, dapsone treatment resolves the skin lesions but does not influence the auto-antigen-antibody complexes that were generating the problem.

Given that $\sim 30 \%$ of GB patients develop seizures, an intriguing and felicitous side note- dapsone has preclinical evidence of significant anti-seizure activity [89-92] and a single open-label study in humans confirming this [93]. This, plus dapsone's demonstrable neuroprotection in animal models [94-96] together constitutes indirect evidence of its ability to pass the blood-brain barrier. There is no published data on direct measurement of dapsone in CSF or brain parenchyma. The pharmacokinetics of dapsone are given in Zuidema et al [97].

\section{Cimetidine}

The widely available, inexpensive histamine receptor 2 blocking drug cimetidine $800 \mathrm{mg}$ every $12 \mathrm{~h}$ reduces incidence and extent of dapsone related methaemoglobin, improving dapsone's therapeutic index by reducing dapsone's N-hydroxylation [98-100].

Coincidentally, cimetidine itself has extensive preclinical, and some limited clinical evidence for an anti-cancer growth effect. A comprehensive review of the potential for inhibiting cancer growth, including anti-glioblastoma aspects of cimetidine, was published in 2014 [101]. Cimetidine inhibits histamine receptor 2, the renal organic cation transporter 2, and multiple hepatic CYP enzymes, most prominently CYP1A2, CYP2D6, and CYP3A4. As a consequence, the half-life of many drugs is prolonged during cimetidine use.

\section{Conclusions}

Clinicians must weigh the not inconsiderable risks of chronic dapsone with the unproven potential benefits as outlined in this paper. Given the uniformity of fatal outcome within two years following initial diagnosis, a small pilot study of $100 \mathrm{mg}$ dapsone twice 
daily with cimetidine $400 \mathrm{mg}$ twice daily is warranted as adjuvant to current standard resection followed by temozolomide chemoirradiation.

There are many more elements driving GB growth other than IL-8 and neutrophils. But any small growth promoting element that we can deprive GB of furthers our goal of long-term control. Preclinical and clinical data indicate that dapsone may contribute, even if slightly, to that goal of reducing IL-8/neutrophil contributions.

Funding: This was unfunded research carried out under the aegis of the IIAIGC Study Center. The IIAIGC had no influence on any matter related to this work.

Institutional Review Board Statement: Not applicable.

Informed Consent Statement: Not applicable.

Data Availability Statement: All data has been presented in the published paper.

Conflicts of Interest: The author declares no conflict of interest.

$\begin{array}{ll}\text { Abbreviations } & \\ \text { glioblastoma } & \text { (GB) } \\ \text { interleukin-1 beta } & \text { (IL-1b) } \\ \text { interleukin-8 } & \text { (IL-8) } \\ \text { vascular endothelial growth factor } & \text { (VEGF) }\end{array}$

\section{References}

1. Anzengruber, F.; Schenk, J.; Graf, V.; Nordmann, T.M.; Guenova, E.; Dummer, R. Dapsone in a Large Tertiary Center: Outdated Therapeutic Option or Timeless Agent? Dermatology 2020, 236, 183-190. [CrossRef] [PubMed]

2. Karpel-Massler, G.; Kast, R.E.; Siegelin, M.D.; Dwucet, A.; Schneider, E.; Westhoff, M.A.; Wirtz, C.R.; Chen, X.Y.; Halatsch, M.E.; Bolm, C. Anti-glioma Activity of Dapsone and Its Enhancement by Synthetic Chemical Modification. Neurochem. Res. 2017, 42, 3382-3389. [CrossRef]

3. Boccellino, M.; Quagliuolo, L.; Alaia, C.; Grimaldi, A.; Addeo, R.; Nicoletti, G.F.; Kast, R.E.; Caraglia, M. The strange connection between epidermal growth factor receptor tyrosine kinase inhibitors and dapsone: From rash mitigation to the increase in anti-tumor activity. Curr. Med. Res. Opin. 2016, 32, 1839-1848. [CrossRef]

4. Kast, R.E. Erlotinib augmentation with dapsone for rash mitigation and increased anti-cancer effectiveness. Springerplus 2015, 4 , 638. [CrossRef] [PubMed]

5. Kast, R.E.; Lefranc, F.; Karpel-Massler, G.; Halatsch, M.E. Why dapsone stops seizures and may stop neutrophils' delivery of VEGF to glioblastoma. Br. J. Neurosurg. 2012, 26, 813-817. [CrossRef] [PubMed]

6. Kast, R.E.; Scheuerle, A.; Wirtz, C.R.; Karpel-Massler, G.; Halatsch, M.E. The rationale of targeting neutrophils with dapsone during glioblastoma treatment. Anticancer Agents Med. Chem. 2011, 11, 756-761. [CrossRef]

7. Ghaoui, N.; Hanna, E.; Abbas, O.; Kibbi, A.G.; Kurban, M. Update on the use of dapsone in dermatology. Int. J. Dermatol. 2020, 59, 787-795. [CrossRef]

8. Miyamoto, D.; Santi, C.G.; Aoki, V.; Maruta, C.W. Bullous pemphigoid. An. Bras. Dermatol. 2019, 94, 133-146. [CrossRef] [PubMed]

9. Gusdorf, L.; Lipsker, D. Neutrophilic urticarial dermatosis: A review. Ann. Dermatol. Venereol. 2018, 145, 735-740. [CrossRef]

10. Alkeraye, S.; AlZamil, L.R.; Alenazi, S. Dapsone in the Management of Pemphigus and Pemphigoid: Rediscovery of its Long-Lost Efficacy. Cureus 2020, 12, e8805. [CrossRef] [PubMed]

11. Sharma, I.; Singh, A.; Siraj, F.; Saxena, S. IL-8/CXCR1/2 signalling promotes tumor cell proliferation, invasion and vascular mimicry in glioblastoma. J. Biomed. Sci. 2018, 25, 62. [CrossRef] [PubMed]

12. Kosmopoulos, M.; Christofides, A.; Drekolias, D.; Zavras, P.D.; Gargalionis, A.N.; Piperi, C. Critical Role of IL-8 Targeting in Gliomas. Curr. Med. Chem. 2018, 25, 1954-1967. [CrossRef]

13. Conroy, S.; Kruyt, F.A.E.; Wagemakers, M.; Bhat, K.P.L.; den Dunnen, W.F.A. IL-8 associates with a pro-angiogenic and mesenchymal subtype in glioblastoma. Oncotarget 2018, 9, 15721-15731. [CrossRef]

14. Angara, K.; Borin, T.F.; Rashid, M.H.; Lebedyeva, I.; Ara, R.; Lin, P.C.; Iskander, A.; Bollag, R.J.; Achyut, B.R.; Arbab, A.S. CXCR2-Expressing Tumor Cells Drive Vascular Mimicry in Antiangiogenic Therapy Resistant Glioblastoma. Neoplasia 2018, 20, 1070-1082. [CrossRef]

15. Liu, Y.S.; Hsu, J.W.; Lin, H.Y.; Lai, S.W.; Huang, B.R.; Tsai, C.F.; Lu, D.Y. Bradykinin B1 receptor contributes to interleukin-8 production and glioblastoma migration through interaction of STAT3 and SP-1. Neuropharmacology 2019, 144, 143-154. [CrossRef] [PubMed] 
16. Zhang, B.; Shi, L.; Lu, S.; Sun, X.; Liu, Y.; Li, H.; Wang, X.; Zhao, C.; Zhang, H.; Wang, Y. Autocrine IL-8 promotes F-actin polymerization and mediate mesenchymal transition via ELMO1-NF-кB-Snail signaling in glioma. Cancer Biol. Ther. 2015, 16, 898-911. [CrossRef]

17. Raychaudhuri, B.; Vogelbaum, M.A. IL-8 is a mediator of NF-kB induced invasion by gliomas. J. Neurooncol. 2011, 101, 227-235. [CrossRef] [PubMed]

18. Hasan, T.; Caragher, S.P.; Shireman, J.M.; Park, C.H.; Atashi, F.; Baisiwala, S.; Lee, G.; Guo, D.; Wang, J.Y.; Dey, M.; et al. Interleukin-8/CXCR2 signaling regulates therapy-induced plasticity and enhances tumorigenicity in glioblastoma. Cell Death Dis. 2019, 10, 292. [CrossRef]

19. Guequén, A.; Zamorano, P.; Córdova, F.; Koning, T.; Torres, A.; Ehrenfeld, P.; Boric, M.P.; Salazar-Onfray, F.; Gavard, J.; Durán, W.N.; et al. Interleukin-8 Secreted by Glioblastoma Cells Induces Microvascular Hyperpermeability Through NO Signaling Involving S-Nitrosylation of VE-Cadherin and p120 in Endothelial Cells. Front Physiol. 2019, 10, 988. [CrossRef]

20. Rajani, K.R.; Carlstrom, L.P.; Parney, I.F.; Johnson, A.J.; Warrington, A.E.; Burns, T.C. Harnessing Radiation Biology to Augment Immunotherapy for Glioblastoma. Front. Oncol. 2019, 8, 656. [CrossRef]

21. Gupta, K.; Burns, T.C. Radiation-Induced Alterations in the Recurrent Glioblastoma Microenvironment: Therapeutic Implications. Front. Oncol. 2018, 8, 503. [CrossRef]

22. Tabatabaei, P.; Visse, E.; Bergström, P.; Brännström, T.; Siesjö, P.; Bergenheim, A.T. Radiotherapy induces an immediate inflammatory reaction in malignant glioma: A clinical microdialysis study. J. Neurooncol. 2017, 131, 83-92. [CrossRef]

23. Pasi, F.; Facoetti, A.; Nano, R. IL-8 and IL-6 bystander signalling in human glioblastoma cells exposed to gamma radiation. Anticancer Res. 2010, 30, 2769-2772.

24. Facoetti, A.; Ballarini, F.; Cherubini, R.; Gerardi, S.; Nano, R.; Ottolenghi, A.; Prise, K.M.; Trott, K.R.; Zilio, C. Gamma ray-induced bystander effect in tumour glioblastoma cells: A specific study on cell survival, cytokine release and cytokine receptors. Radiat. Prot. Dosimetry 2006, 122, 271-274. [CrossRef] [PubMed]

25. Xu, R.X.; Liu, R.Y.; Wu, C.M.; Zhao, Y.S.; Li, Y.; Yao, Y.Q.; Xu, Y.H. DNA damage-induced NF-kB activation in human glioblastoma cells promotes miR-181b expression and cell proliferation. Cell Physiol. Biochem. 2015, 35, 913-925. [CrossRef] [PubMed]

26. Yang, L.; Liu, Z.; Wu, R.; Yao, Q.; Gu, Z.; Liu, M. Correlation of C-X-C chemokine receptor 2 upregulation with poor prognosis and recurrence in human glioma. OncoTargets Ther. 2015, 8, 3203-3209. [CrossRef]

27. Lee, K.H.; Park, J.H.; Kim, D.H.; Hwang, J.; Lee, G.; Hyun, J.S.; Heo, S.T.; Choi, J.H.; Kim, M.; Kim, M.; et al. Dapsone as a potential treatment option for Henoch-Schönlein Purpura (HSP). Med. Hypotheses 2017, 108, 42-45. [CrossRef] [PubMed]

28. Lan, C.C.; Wu, C.S.; Huang, S.M.; Wu, I.H.; Chen, G.S. High-glucose environment enhanced oxidative stress and increased interleukin-8 secretion from keratinocytes: New insights into impaired diabetic wound healing. Diabetes 2013, 62, $2530-2538$. [CrossRef] [PubMed]

29. Abe, M.; Shimizu, A.; Yokoyama, Y.; Takeuchi, Y.; Ishikawa, O. A possible inhibitory action of diaminodiphenyl sulfone on tumour necrosis factor-alpha production from activated mononuclear cells on cutaneous lupus erythematosus. Clin. Exp. Dermatol. 2008, 33, 759-763. [CrossRef]

30. Schmidt, E.; Reimer, S.; Kruse, N.; Bröcker, E.B.; Zillikens, D. The IL-8 release from cultured human keratinocytes, mediated by antibodies to bullous pemphigoid autoantigen 180, is inhibited by dapsone. Clin. Exp. Immunol. 2001, 124, 157-162. [CrossRef] [PubMed]

31. Kanoh, S.; Tanabe, T.; Rubin, B.K. Dapsone inhibits IL-8 secretion from human bronchial epithelial cells stimulated with lipopolysaccharide and resolves airway inflammation in the ferret. Chest 2011, 140, 980-990. [CrossRef] [PubMed]

32. Booth, S.A.; Moody, C.E.; Dahl, M.V.; Herron, M.J.; Nelson, R.D. Dapsone suppresses integrin-mediated neutrophil adherence function. J. Investig. Dermatol. 1992, 98, 135-140. [CrossRef]

33. Geyfman, M.; Debabov, D.; Poloso, N.; Alvandi, N. Mechanistic insight into the activity of a sulfone compound dapsone on Propionibacterium (Newly Reclassified as Cutibacterium) Acnes-mediated cytokine production. Exp. Dermatol. 2019, 28, 190-197. [CrossRef] [PubMed]

34. Bellon, H.; Vandermeulen, E.; Mathyssen, C.; Sacreas, A.; Verleden, S.E.; Heigl, T.; Vriens, H.; Lammertyn, E.; Pilette, C.; Hoet, P.; et al. Interleukin- $1 \alpha$ induced release of interleukin- 8 by human bronchial epithelial cells in vitro: Assessing mechanisms and possible treatment options. Transpl. Int. 2017, 30, 388-397. [CrossRef] [PubMed]

35. Ahn, S.H.; Park, H.; Ahn, Y.H.; Kim, S.; Cho, M.S.; Kang, J.L.; Choi, Y.H. Necrotic cells influence migration and invasion of glioblastoma via NF-кB/AP-1-mediated IL-8 regulation. Sci. Rep. 2016, 6, 24552. [CrossRef]

36. Rahbar, A.; Cederarv, M.; Wolmer-Solberg, N.; Tammik, C.; Stragliotto, G.; Peredo, I.; Fornara, O.; Xu, X.; Dzabic, M.; Taher, C.; et al. Enhanced neutrophil activity is associated with shorter time to tumor progression in glioblastoma patients. Oncoimmunology 2015, 5, e1075693. [CrossRef]

37. Svendsen, M.N.; Lykke, J.; Werther, K.; Christensen, I.J.; Nielsen, H.J. Concentrations of VEGF and VEGFR1 in paired tumor arteries and veins in patients with rectal cancer. Oncol. Res. 2004, 14, 611-615. [CrossRef]

38. Werther, K.; Bülow, S.; Hesselfeldt, P.; Jespersen, N.F.; Svendsen, M.N.; Nielsen, H.J. VEGF concentrations in tumour arteries and veins from patients with rectal cancer. APMIS 2002, 110, 646-650. [PubMed]

39. Kusumanto, Y.H.; Dam, W.A.; Hospers, G.A.; Meijer, C.; Mulder, N.H. Platelets and granulocytes, in particular the neutrophils, form important compartments for circulating vascular endothelial growth factor. Angiogenesis 2003, 6, 283-287. [CrossRef] 
40. Han, S.; Liu, Y.; Li, Q.; Li, Z.; Hou, H.; Wu, A. Pre-treatment neutrophil-to-lymphocyte ratio is associated with neutrophil and T-cell infiltration and predicts clinical outcome in patients with glioblastoma. BMC Cancer 2015, 15, 617. [CrossRef]

41. Saito, T.; Sugiyama, K.; Hama, S.; Yamasaki, F.; Takayasu, T.; Nosaka, R.; Muragaki, Y.; Kawamata, T.; Kurisu, K. Prognostic importance of temozolomide-induced neutropenia in glioblastoma, IDH-wildtype patients. Neurosurg. Rev. 2018, 41, 621-628. [CrossRef]

42. Nowosielski, M.; Gorlia, T.; Bromberg, J.E.C.; Sahm, F.; Harting, I.; Kickingereder, P.; Brandes, A.A.; Taphoorn, M.J.B.; Taal, W.; Domont, J.; et al. Imaging necrosis during treatment is associated with worse survival in EORTC 26101 study. Neurology 2019, 92, e2754-e2763. [CrossRef]

43. Zhang, C.; Cheng, W.; Ren, X.; Wang, Z.; Liu, X.; Li, G.; Han, S.; Jiang, T.; Wu, A. Tumor Purity as an Underlying Key Factor in Glioma. Clin. Cancer Res. 2017, 23, 6279-6291. [CrossRef] [PubMed]

44. Pitter, K.L.; Tamagno, I.; Alikhanyan, K.; Hosni-Ahmed, A.; Pattwell, S.S.; Donnola, S.; Dai, C.; Ozawa, T.; Chang, M.; Chan, T.A.; et al. Corticosteroids compromise survival in glioblastoma. Brain 2016, 139, 1458-1471. [CrossRef]

45. Wong, E.T.; Lok, E.; Gautam, S.; Swanson, K.D. Dexamethasone exerts profound immunologic interference on treatment efficacy for recurrent glioblastoma. Br. J. Cancer 2015, 113, 232-241. [CrossRef]

46. Schernberg, A.; Nivet, A.; Dhermain, F.; Ammari, S.; Escande, A.; Pallud, J.; Louvel, G.; Deutsch, E. Neutrophilia as a biomarker for overall survival in newly diagnosed high-grade glioma patients undergoing chemoradiation. Clin. Transl. Radiat. Oncol. 2018, 10, 47-52. [CrossRef] [PubMed]

47. Dubinski, D.; Won, S.Y.; Gessler, F.; Quick-Weller, J.; Behmanesh, B.; Bernatz, S.; Forster, M.T.; Franz, K.; Plate, K.H.; Seifert, V.; et al. Dexamethasone-induced leukocytosis is associated with poor survival in newly diagnosed glioblastoma. J. Neurooncol. 2018, 137, 503-510. [CrossRef]

48. Hui, C.Y.; Rudra, S.; Ma, S.; Campian, J.L.; Huang, J. Impact of overall corticosteroid exposure during chemoradiotherapy on lymphopenia and survival of glioblastoma patients. J. Neurooncol. 2019, 143, 129-136. [CrossRef] [PubMed]

49. Ly, K.H.; Dalmay, F.; Gondran, G.; Palat, S.; Bezanahary, H.; Cypierre, A.; Fauchais, A.L.; Liozon, E. Steroid-sparing effect and toxicity of dapsone treatment in giant cell arteritis: A single-center, retrospective study of 70 patients. Medicine 2016, 95 , e4974. [CrossRef]

50. Hurt, B.; Schulick, R.; Edil, B.; El Kasmi, K.C.; Barnett, C., Jr. Cancer-promoting mechanisms of tumor-associated neutrophils. Am. J. Surg. 2017, 214, 938-944. [CrossRef]

51. Powell, D.R.; Huttenlocher, A. Neutrophils in the Tumor Microenvironment. Trends Immunol. 2016, 37, 41-52. [CrossRef]

52. Liang, J.; Piao, Y.; Holmes, L.; Fuller, G.N.; Henry, V.; Tiao, N.; de Groot, J.F. Neutrophils promote the malignant glioma phenotype through S100A4. Clin. Cancer Res. 2014, 20, 187-198. [CrossRef] [PubMed]

53. Schiffmann, L.M.; Fritsch, M.; Gebauer, F.; Günther, S.D.; Stair, N.R.; Seeger, J.M.; Thangarajah, F.; Dieplinger, G.; Bludau, M.; Alakus, H.; et al. Tumour-infiltrating neutrophils counteract anti-VEGF therapy in metastatic colorectal cancer. Br. J. Cancer 2019, 120, 69-78. [CrossRef]

54. Quillien, V.; Carpentier, A.F.; Gey, A.; Avril, T.; Tartour, E.; Sejalon, F.; Campillo-Gimenez, B.; Vauleon, E. Absolute numbers of regulatory $\mathrm{T}$ cells and neutrophils in corticosteroid-free patients are predictive for response to bevacizumab in recurrent glioblastoma patients. Cancer Immunol. Immunother. 2019, 68, 871-882. [CrossRef] [PubMed]

55. Bertaut, A.; Truntzer, C.; Madkouri, R.; Kaderbhai, C.G.; Derangère, V.; Vincent, J.; Chauffert, B.; Aubriot-Lorton, M.H.; Farah, W.; Mourier, K.L.; et al. Blood baseline neutrophil count predicts bevacizumab efficacy in glioblastoma. Oncotarget 2016, 7, 70948-70958. [CrossRef] [PubMed]

56. Owen-Woods, C.; Joulia, R.; Barkaway, A.; Rolas, L.; Ma, B.; Nottebaum, A.F.; Arkill, K.P.; Stein, M.; Girbl, T.; Golding, M.; et al. Local microvascular leakage promotes trafficking of activated neutrophils to remote organs. J. Clin. Investig. 2020, 130, 2301-2318. [CrossRef]

57. Luo, X.; Xu, S.; Zhong, Y.; Tu, T.; Xu, Y.; Li, X.; Wang, B.; Yang, F. High gene expression levels of VEGFA and CXCL8 in the peritumoral brain zone are associated with the recurrence of glioblastoma: A bioinformatics analysis. Oncol. Lett. 2019, 18, 6171-6179. [CrossRef] [PubMed]

58. Mastio, J.; Condamine, T.; Dominguez, G.; Kossenkov, A.V.; Donthireddy, L.; Veglia, F.; Lin, C.; Wang, F.; Fu, S.; Zhou, J.; et al. Identification of monocyte-like precursors of granulocytes in cancer as a mechanism for accumulation of PMN-MDSCs. J. Exp. Med. 2019, 216, 2150-2169. [CrossRef]

59. Locarno, C.V.; Simonelli, M.; Carenza, C.; Capucetti, A.; Stanzani, E.; Lorenzi, E.; Persico, P.; Della Bella, S.; Passoni, L.; Mavilio, D.; et al. Role of myeloid cells in the immunosuppressive microenvironment in gliomas. Immunobiology 2020, 225, 151853. [CrossRef]

60. Triner, D.; Shah, Y.M. Hypoxic Regulation of Neutrophils in Cancer. Int. J. Mol. Sci. 2019, 20, 4189. [CrossRef]

61. Gielen, P.R.; Schulte, B.M.; Kers-Rebel, E.D.; Verrijp, K.; Bossman, S.A.; Ter Laan, M.; Wesseling, P.; Adema, G.J. Elevated levels of polymorphonuclear myeloid-derived suppressor cells in patients with glioblastoma highly express S100A8/9 and arginase and suppress T cell function. Neuro Oncol. 2016, 18, 1253-1264. [CrossRef] [PubMed]

62. Massara, M.; Persico, P.; Bonavita, O.; Mollica Poeta, V.; Locati, M.; Simonelli, M.; Bonecchi, R. Neutrophils in Gliomas. Front Immunol. 2017, 8, 1349. [CrossRef]

63. Khan, S.; Mittal, S.; McGee, K.; Alfaro-Munoz, K.D.; Majd, N.; Balasubramaniyan, V.; de Groot, J.F. Role of Neutrophils and Myeloid-Derived Suppressor Cells in Glioma Progression and Treatment Resistance. Int. J. Mol. Sci. 2020, 21, 1954. [CrossRef] 
64. Wang, P.F.; Zhang, Y.X.; Su, J.; Yao, K.; Li, S.W.; Huang, G.R.; Yan, C.X. Neutrophil depletion enhances the therapeutic effect of PD-1 antibody on glioma. Aging 2020, 12, 15290-15301. [CrossRef]

65. Zhao, B.; Wang, Y.; Wang, Y.; Chen, W.; Liu, P.H.; Kong, Z.; Dai, C.; Wang, Y.; Ma, W. Systematic identification, development, and validation of prognostic biomarkers involving the tumor-immune microenvironment for glioblastoma. J. Cell Physiol. 2020. [CrossRef]

66. Gan, Y.; Zhou, X.; Niu, X.; Li, J.; Wang, T.; Zhang, H.; Yang, Y.; Liu, Y.; Mao, Q. Neutrophil-lymphocyte ratio (NLR) is an independent prognostic factor in the elderly patients with high-grade gliomas. World Neurosurg. 2019, 127, e261-e267. [CrossRef]

67. Weng, W.; Chen, X.; Gong, S.; Guo, L.; Zhang, X. Preoperative neutrophil-lymphocyte ratio correlated with glioma grading and glioblastoma survival. Neurol. Res. 2018, 40, 917-922. [CrossRef]

68. Hao, Y.; Li, X.; Chen, H.; Huo, H.; Liu, Z.; Tian, F.; Chai, E. A Cumulative Score Based on Preoperative Neutrophil-Lymphocyte Ratio and Fibrinogen in Predicting Overall Survival of Patients with Glioblastoma Multiforme. World Neurosurg. 2019, 128, e427-e433. [CrossRef] [PubMed]

69. Zheng, S.H.; Huang, J.L.; Chen, M.; Wang, B.L.; Ou, Q.S.; Huang, S.Y. Diagnostic value of preoperative inflammatory markers in patients with glioma: A multicenter cohort study. J. Neurosurg. 2018, 129, 583-592. [CrossRef] [PubMed]

70. Altundag, K. Prognostic effect of neutrophil-lymphocyte ratio during concurrent chemo-radiotherapy period in glioblastoma patients who did not receive dexamethasone. J. Neurooncol. 2018, 136, 217. [CrossRef]

71. Lopes, M.; Carvalho, B.; Vaz, R.; Linhares, P. Influence of neutrophil-lymphocyte ratio in prognosis of glioblastoma multiforme. J. Neurooncol. 2018, 136, 173-180. [CrossRef] [PubMed]

72. Wang, Z.L.; Zhang, C.B.; Liu, Y.Q.; Wang, Z.; Jiang, T. Peripheral blood test provides a practical method for glioma evaluation and prognosis prediction. CNS Neurosci. Ther. 2019, 25, 876-883. [CrossRef] [PubMed]

73. Wang, Z.; Zhong, L.; Li, G.; Huang, R.; Wang, Q.; Wang, Z.; Zhang, C.; Chen, B.; Jiang, T.; Zhang, W. Pre-treatment neutrophils count as a prognostic marker to predict chemotherapeutic response and survival outcomes in glioma: A single-center analysis of 288 cases. Am. J. Transl. Res. 2020, 12, 90-104. [PubMed]

74. Brenner, A.; Friger, M.; Geffen, D.B.; Kaisman-Elbaz, T.; Lavrenkov, K. The Prognostic Value of the Pretreatment Neutrophil/Lymphocyte Ratio in Patients with Glioblastoma Multiforme Brain Tumors: A Retrospective Cohort Study of Patients Treated with Combined Modality Surgery, Radiation Therapy, and Temozolomide Chemotherapy. Oncology 2019, 97, $255-263$. [CrossRef]

75. Mermut, O.; Inanc, B. The effect of indicators of systemic inflammatory response on survival in glioblastoma multiforme. Turk. Neurosurg. 2019. [CrossRef]

76. Marini, A.; Dobran, M.; Aiudi, D.; Pesaresi, A.; di Somma, L.G.M.; Iacoangeli, M. Pre-operative hematological markers as predictive factors for overall survival and progression free survival in glioblastomas. Clin. Neurol. Neurosurg. 2020, $197,106162$. [CrossRef] [PubMed]

77. Zhang, X.; Li, C.; Xiao, L.; Gao, C.; Zhao, W.; Yang, M.; Sun, T.; Wang, F. Predicting Individual Prognosis and Grade of Patients with Glioma Based on Preoperative Eosinophil and Neutrophil-to-Lymphocyte Ratio. Cancer Manag. Res. 2020, 12, 5793-5802. [CrossRef]

78. Zha, C.; Meng, X.; Li, L.; Mi, S.; Qian, D.; Li, Z.; Wu, P.; Hu, S.; Zhao, S.; Cai, J.; et al. Neutrophil extracellular traps mediate the crosstalk between glioma progression and the tumor microenvironment via the HMGB1/RAGE/IL-8 axis. Cancer Biol. Med. 2020, 17, 154-168. [CrossRef] [PubMed]

79. Lee, J.H.; An, H.K.; Sohn, M.G.; Kivela, P.; Oh, S. 4,4'-Diaminodiphenyl Sulfone (DDS) as an Inflammasome Competitor. Int. J. Mol. Sci. 2020, 21, 5953. [CrossRef]

80. Atukeren, P.; Kemerdere, R.; Kacira, T.; Hanimoglu, H.; Ozlen, F.; Yavuz, B.; Tanriverdi, T.; Gumustas, K.; Canbaz, B. Expressions of some vital molecules: Glioblastoma multiforme versus normal tissues. Neurol. Res. 2010, 32, 492-501. [CrossRef]

81. Aaltonen, N.; Singha, P.K.; Jakupović, H.; Wirth, T.; Samaranayake, H.; Pasonen-Seppänen, S.; Rilla, K.; Varjosalo, M.; EdgingtonMitchell, L.E.; Kasperkiewicz, P.; et al. High-Resolution Confocal Fluorescence Imaging of Serine Hydrolase Activity in Cryosections-Application to Glioma Brain Unveils Activity Hotspots Originating from Tumor-Associated Neutrophils. Biol. Proc. Online 2020, 22, 6. [CrossRef] [PubMed]

82. Deps, P.; Guerra, P.; Nasser, S.; Simon, M. Hemolytic anemia in patients receiving daily dapsone for the treatment of leprosy. Lepr. Rev. 2012, 83, 305-307. [CrossRef]

83. Fowler, P.D.; Shadforth, M.F.; Crook, P.R.; Lawton, A. Report on chloroquine and dapsone in the treatment of rheumatoid arthritis: A 6-month comparative study. Ann. Rheum. Dis. 1984, 43, 200-204. [CrossRef]

84. Chang, D.J.; Lamothe, M.; Stevens, R.M.; Sigal, L.H. Dapsone in rheumatoid arthritis. Semin. Arthritis Rheum. 1996, 25, 390-403. [CrossRef]

85. Swinson, D.R.; Zlosnick, J.; Jackson, L. Double-blind trial of dapsone against placebo in the treatment of rheumatoid arthritis. Ann. Rheum. Dis. 1981, 40, 235-239. [CrossRef]

86. Klebes, M.; Wutte, N.; Aberer, E. Dapsone as Second-Line Treatment for Cutaneous Lupus Erythematosus? A Retrospective Analysis of 34 Patients and a Review of the Literature. Dermatology 2016, 232, 91-96. [CrossRef]

87. Lewis, J.S.; Jacobs, Z.G. Subtle case of dapsone-induced methaemoglobinaemia. BMJ Case Rep. 2020, 13, e235403. [CrossRef]

88. Spring, I.R.; Ilangaratne, C.; Walsh, S. HbA1C levels: Falsely low in a patient taking dapsone. Clin. Exp. Dermatol. 2020. [CrossRef] [PubMed] 
89. Ríos, C.; Farfán-Briseño, A.C.; Manjarrez-Marmolejo, J.; Franco-Pérez, J.; Méndez-Armenta, M.; Nava-Ruiz, C.; Caballero-Chacón, S.; Ruiz-Diaz, A.; Baron-Flores, V.; Díaz-Ruiz, A. Efficacy of dapsone administered alone or in combination with diazepam to inhibit status epilepticus in rats. Brain Res. 2019, 1708, 181-187. [CrossRef] [PubMed]

90. Diaz-Ruiz, A.; Mendez-Armenta, M.; Galván-Arzate, S.; Manjarrez, J.; Nava-Ruiz, C.; Santander, I.; Balderas, G.; Ríos, C. Antioxidant, anticonvulsive and neuroprotective effects of dapsone and phenobarbital against kainic acid-induced damage in rats. Neurochem. Res. 2013, 38, 1819-1827. [CrossRef] [PubMed]

91. Ishida, S.; Hamada, K.; Yagi, K.; Seino, M. Comparing the anticonvulsive effects of dapsone on amygdala-kindled seizures and hippocampal-kindled seizures in rats. Acta Neurol. Scand. 1992, 85, 132-135. [CrossRef] [PubMed]

92. Hamada, K.; Hiyoshi, T.; Kobayashi, S.; Ishida, S.; Yagi, K.; Seino, M. Anticonvulsive effect of dapsone (4,4'-diaminodiphenyl sulfone) on amygdala-kindled seizures in rats and cats. Epilepsy Res. 1991, 10, 93-102. [CrossRef]

93. López-Gómez, M.; Corona, T.; Diaz-Ruiz, A.; Ríos, C. Safety and tolerability of dapsone for the treatment of patients with drug-resistant, partial-onset seizures: An open-label trial. Neurol. Sci. 2011, 32, 1063-1067. [CrossRef]

94. Rodríguez, E.; Méndez-Armenta, M.; Villeda-Hernández, J.; Galván-Arzate, S.; Barroso-Moguel, R.; Rodríguez, F.; Ríos, C.; Santamaría, A. Dapsone prevents morphological lesions and lipid peroxidation induced by quinolinic acid in rat corpus striatum. Toxicology 1999, 139, 111-118. [CrossRef]

95. Santamaría, A.; Ordaz-Moreno, J.; Rubio-Osornio, M.; Solís-Hernández, F.; Ríos, C. Neuroprotective effect of dapsone against quinolinate- and kainate-induced striatal neurotoxicities in rats. Pharmacol. Toxicol. 1997, 81, 271-275.

96. Yang, N.; Li, L.; Li, Z.; Ni, C.; Cao, Y.; Liu, T.; Tian, M.; Chui, D.; Guo, X. Protective effect of dapsone on cognitive impairment induced by propofol involves hippocampal autophagy. Neurosci. Lett. 2017, 649, 85-92. [CrossRef]

97. Zuidema, J.; Hilbers-Modderman, E.S.; Merkus, F.W. Clinical pharmacokinetics of dapsone. Clin. Pharmacokinet. 1986, 11, $299-315$. [CrossRef]

98. Coleman, M.D. Dapsone. modes of action, toxicity and possible strategies for increasing patient tolerance. Br. J. Dermatol. 1993, 129, 507-513.

99. Goolamali, S.I.; Macfarlane, C.S. The use of cimetidine to reduce dapsone-dependent haematological side-effects in a patient with mucous membrane pemphigoid. Clin. Exp. Dermatol. 2009, 34, e1025-e1026. [CrossRef]

100. Rhodes, L.E.; Tingle, M.D.; Park, B.K.; Chu, P.; Verbov, J.L.; Friedmann, P.S. Cimetidine improves the therapeutic/toxic ratio of dapsone in patients on chronic dapsone therapy. Br. J. Dermatol. 1995, 132, 257-262. [CrossRef]

101. Pantziarka, P.; Bouche, G.; Meheus, L.; Sukhatme, V.; Sukhatme, V.P. Repurposing drugs in oncology (ReDO)-cimetidine as an anti-cancer agent. Ecancermedicalscience 2014, 8, 485. [CrossRef] [PubMed] 